\title{
郵政建築における建築生産システムの変容に関する一考察 HISTORICAL STUDY OF POSTAL ARCHITECTURE SYSTEM AND MANAGEMENT
}

\author{
齋藤隆司*, 古阪秀三**, 平野吉信*** \\ Takashi SAITO, Shuzo FURUSAKA and Yoshinobu HIRANO
}

\begin{abstract}
This paper analyses the influence of postal architecture's quality assurance from the view point of client side. Postal architecture is very unique tradition, having both clients and architects function in the organization.

Postal architecture was born in 1885, with over 130 years' historical accomplishment. The era of postal architecture has been divided into 4 phases; 1) the era of in-house designers who lead building projects, 2) era of specialists, 3) era of project management, 4) era of externalities and privatization.

This paper analyses the changing role of clients and how the environment society has been influenced these changes.
\end{abstract}

Keywords: Postal Architecture, Supervision, Post Office, Client, Quality

郵政建築, 工事監理, 郵便局, 発注者, 品質

\section{1 はじめに}

\section{$1-1$ 研究の背景と目的}

アベノミクス効果もあり経済の改善が進む一方、工事費の上昇や 施工品質への懸念が増加している。公共工事においては不調、不落 等も多数生じている。公共工事では発注者責任のあり方について、 長年の課題として、総合評価方式の採用や「発注者責任を果たすた めの今後の建設生産・管理システムのあり方に関する㸸談会注 1)」を 設置し、公共発注者としてのあるべき姿を探っている。このような 環境の中、建築プロジェクトにおける「発注者」としての役割と責 任のあり方が、ますます重要となってきている。

郵政は莪信省時代から、発注者として、東京中央郵便局・大阪中 央郵便局の吉田鉄郎や旧東京逓信病院の山田守、戦後の郵政省時代 の旧東京郵政局の小坂秀雄の作品等、日本近代建築を代表する建築 家を生み出してきた。1) 郵政建築は、明治初期から郵便局を中心に 特定の建築物を整備するため、発注者注 2) としての役割を担いつつ、 社会環境の変化に対応して、設計者、監督員の役割を変化させるこ とで、一定の品質を確保してきた。特に、郵政職員自らが建設プロ セスに関与することで、発注者でありがなら、自ら設計業務を実施、 施工者が実施する業務の一部を管理するなど、郵政建築にとって必 要な品質レベルの高い建物とそれを実現するための建築生産システ ムを確保してきた特徵を持つ。

本研究は、発注者として建築プロジェクトに関与してきた歴史を
持つ郵政建築が、いかに建築生産システムに関わり変容してきたの かを明らかにすることで、発注者責任が問われる今日、建築プロジ エクトにおける発注者の責任や役割のあり方の議論の一助とするも のである。

そこで、本論文では、郵政建築における建築生産システムの変容 過程を郵政建築の組織、発注者機能、設計者機能、監督員機能に絞 って分析し、明らかにすることを目的とする。

なお、本論文で用いる「郵政建築」とは、「莪信省、郵政省から、 郵政事業庁、日本郵政公社、民営化後の郵政組織において生み出し てきた建築及び組織、並びにそれに伴う活動」として定義している。

\section{$1-2$ 既往研究}

郵政建築に関する研究としては丹羽 ${ }^{2)}$ や李 ${ }^{3)}$ の研究がある。これ らはデザイン、建築計画や建築史に関する研究が中心となっている。 また、西野 ${ }^{4)}$ らによる建築プロセスにおける体制の推移と設計内容 の確定過程について、前川國男に代表されるアトリエ系民間設計事 務所を対象にした研究もある。一方、羽田野 ${ }^{5)}$ らは官庁営繮の業務 機能が外部化する過程を明らかにしている。

発注者に関する研究として、水川 ${ }^{6}$ の「建築プロジェクトの発注 者支援業務に関する研究」では、発注者から見た建築プロジェクト の業務階層の構造化を提案している。また、李 ${ }^{7)}$ の「日本と韓国に おける発注者の意識に関する研究」ではアンケート調查に基づき日

\footnotetext{
* 日本郵政(株)不動産部門不動産企画部 部長 ·工修

** 京都大学大学院工学研究科建築学専攻 准教授.工博

*** 広島大学大学院工学研究科建築学専攻 教授·博士 (工学 $)$
}

Deputy Senior General Manager, Japan Post Co., Ltd., M. Eng., M. Sci.

Assoc. Prof., Dept. of Architecture and Architectural Eng., Kyoto University, Dr. Eng. Prof., Dept. of Architecture and Architectural Eng., Hiroshima University, Dr. Eng. 
韓における発注者が選択する工事発注方式の差異を明らかにしてい る。発注者の役割としては、国土交通省を中心に発注者責任に関す る各種研究会が開催され、報告書も発表されている。また、筆者ら による郵政の工事監理に関する研究 ${ }^{8), 9)}$ もる。

これらの研究を参考にしたうえで、郵政建築における建築生産シ ステムの変容について分析を行う。

\section{2 研究の方法}

本研究では、郵政建築の建築生産システムの組織、発注者機能、 設計者機能、監督員機能における変容の過程を明らかにするため、 (1)文献調查、(2)各種規定・基準類、(3)郵政 $O B$ へのインタビューにつ いて、分析を行う。

文献調査では、明治時代における当時の逓信省の営繥業務の活動 内容を知り得る文献として、立花量吉の続聥信事業史建築編序説 ${ }^{10)} 、$ 張菅雄の高等建築学 第 19 巻「莪信省の建築」 ${ }^{11}$ などがある。その 後、逓信事業史、郵政事業史、郵政の営繥組織が発行した機関紙 「郵政建築」12)、「ゆうせい・しせつ」 ${ }^{13)}$ 等を参考に、莪信省に続 く郵政省時代の変容の過程を明らかにする。

また、郵政建築の生産システムの変容の過程の技術的根拠となる 郵政の設計や監督、工事に関する基準、要領等についても、調查分 析を行う。

さらに、資料に記録されていない業務や実際の現場における役割 分担などについて、詳細な検討を実施するため、昭和 30 年代から設 計者及び監督員として現場で指導、監督を実施した旧郵政省建築部 の幹部職員 6 名及び当時のゼネコン現場所長 2 名から、2011 年にイ ンタビューを実施した。主に、品質確保を担保するための(1)発注者 としての郵政職員の役割、(2)設計者と監督員の責任範囲、(3)設計者、 監督員、施工者の役割分担等を中心に聞いている。

昭和 60 年以降については、これらの資料に加えて、外部委託研究 や筆者の郵政建築における経験を加味して、分析を行う。

\section{3 郵政を取り巻く環境の変化}

本章では、郵政建築の変容を見出すために、郵政建築を取り巻く 外部環境の変化、組織の変遷、郵便局等への投資額の推移について 検討する。

\section{3-1 郵政を取り巻く外部環境の変化}

明治から昭和初期までは、全国レベルで言えば建設業者の数も少 なく、また技術力についても、官民を比較すると、比較的官側が優 位であった。しかし建設業法等の施行により、1950 年代から、外部 環境が大きく変化する。

「建設業者の資質向上」「工事請負契約の適正化」を進めるため、 1949 年に建設業法が施行され、1971 年の改正、更に翌年の公共工事 標準請負契約約款策定により、片務契約から双務契約に変わった。 それに伴い、建設業者数も 1950 年代の 5 万社から 2000 年の 60 万社 まで 10 倍を超えるまで、急速に増加している。建築士事務所登録数 についても、1950 年には建築士法が成立し、1980 年の 10 万社から 2000 年には 13.4 万社まで増加しており、外部技術力に依存できる 環境が構築されてきた。さらに、郵政以外の外部の設計者、施工者 による(1)1970 年代における TQC の導入とその後の IS09000 認証取得、 (2)工事監理の指導監督型監理から自主管理確認型監理への移行、(3)
1995 年の WT0 設立に伴う日本の建設市場の国際開放、(4)CM 方式、PM 方式、PFI、第三者監理等を含む発注方式の多様化等、といった外部 環境の変化が、郵政建築における設計者や監督員のあり方に、大き な影響を与えている。

\section{3-2 郵政組織の変遷}

郵便制度は 1871 年に、郵便事業が創業されたことに始まる。1 885 年に逓信省が設置され、郵政建築も同時に始まった。その後、特別 会計の導入により比較的潤沢な予算を確保することができた。戦後、 二省分割により、郵政省と電気通信省に分割され、郵政省として高 度成長期を迎え、工事量も増大した。その後、国の機関の再編を経 て、郵政事業庁、日本郵政公社となり、民営化に伴い日本郵政株式 会社（現日本郵政グループ）へと組織が大きく変わっている。

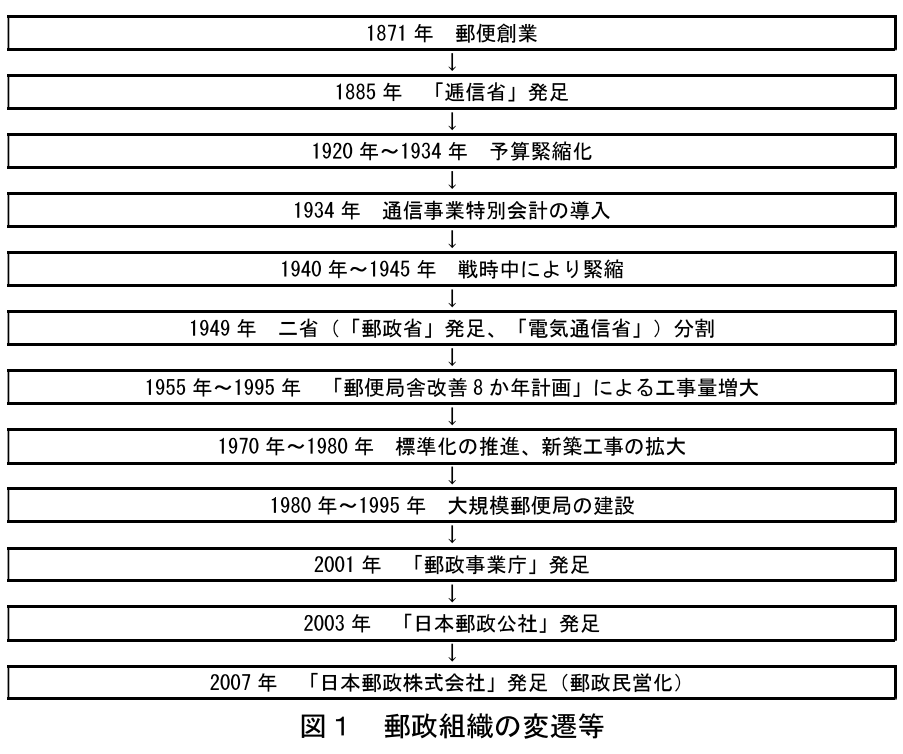

\section{3-3＼cjkstart郵政における郵便局等への投資額の推移}

莪信省における設備投資額は、郵便局や電話局が早急に整備すべ き必要な日本のインフラとされたため、一般の官庁建築と比較して、

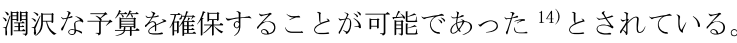

昭和以降の予算措置の推移状況を見ると、昭和初期の 1934 年通信 事業特別会計の導入により、官庁建築の予算執行と異なり年度の縛 りにとらわれることなく複数年度の予算執行や複数プロジェクトの 推進等、独自に予算付けするとともに柔軟な予算執行が可能となっ た。立花 ${ }^{10)}$ によれば、「1936 年の営繥費は特別会計導入前の 1932 年の 42.6 倍になるなど」急激に予算が拡大した。さらに、1955 年 に「郵便局舎改善 8 力年計画」が策定されると、急速に設備投資額 が増加した。その後、1995 年の第 8 次まで同計画は継続された。特 に、1970 年から 1980 年にかけて都市部の人口増もあり、この期間 のみで、全国の大規模かつ主要な郵便局 1,091 局のうち、約 4 割に あたる 403 局が建設されている。

郵政建築における設備投資額の推移は 1990 年代のバブル期に向か って一貫して増加し、1992 年の 1,430 億円をピークに、その後 5 年 間のピーク期が続いた。1999 年からは新規の郵便局建設の抑制もあ り、大幅に投資が減少し、1970 年代の設備投資額とほぼ同じ水準ま で低下している。職員一人当たりの予算額についても、1970 年の 
0.31 億円／人から、1980 年には 1.39 憶円／人、その後も大幅な職 員の増加がなかったことから、ピーク時の 1992 年には、3.43 億円 /人と、1970 年の約 11 倍にもなっている。この間、建設デフレー ター ${ }^{15)}$ が 34.9 から 100.6 と 2.8 倍になっているのを考慮しても、郵 政の職員一人当たりの予算額は建設デフレーターの約 3 倍もの伸び となっており、物価上昇以上に増加している。その後、民営化工事 等の設備投資額の増加を除き、一貫して減少している。

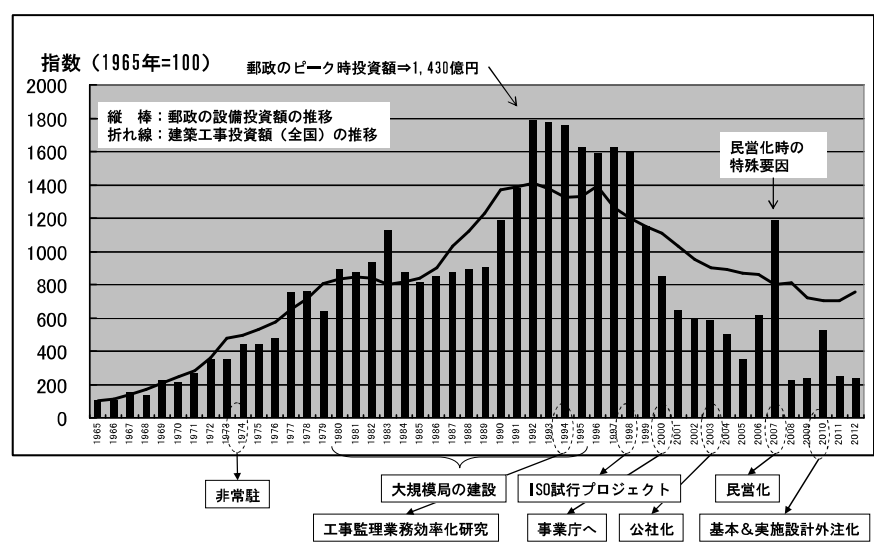

図 2 郵政建築の設備投資額の推移（指数（1965 年=100））

\section{3-4 郵政建築を取り巻く環境変化から生ずる郵政建築の変容}

自らすべての建設プロセスに関わることから、1950 年後半から局 舎改善に伴う工事量、投資額の増加、それに伴う業務量の増大、一 方で、自主管理確認型監理の導入、IS09000 取得等による品質管理 システムの定着など、郵政建築を取り巻く外部環境が整備される中 で、郵政建築も影響を受けていることが推定される。

\section{4 郵政建築における建築生産システムの変容過程}

郵政建築における建築生産システムの変容に関し、(1)建築組織、 (2)発注者機能、(3)設計者機能、(4)監督員機能について、検討を行う。

\section{4-1 建築組織における変容過程}

郵便局の建築は 1873 年まで大蔵省によって担当され、その後、 1874 年営繥事務集約のため工部省営繥課において整備された。しか し、1885 年莪信省設置に伴い、郵便局の建築は会計局用度課（1886 年）で実施されることとなり、これが郵政にける建築の始まりであ る。発注者として工事発注を行う一方、自らが設計、監督する方式 は、逓信省の建築発注でも踏襲されている。その後、二省分割を経 た郵政省においても、建築全般の発注及び設計・監督にかかる業務 は、一貫して、郵政の建築組織自らが実施している。

1960 年代の高度成長期に入ると、設計、施工（監督）、設備、標 準、機械化、保全といった専門組織を次々と立ち上げ、業務量の増 加、専門化に対応している。

1996 年には発注者組織の一部である郵務局施設課を統合する形で、 建築部から施設部へ組織改正を行った。同時に、専門組織を統合す る形で建築企画課、建築業務課を設立し、プロジェクトマネジメン 卜機能を強化している。2003 年の公社化、2007 年の民営化により、 組織と役割が郵政グループ内の設計事務所としての位置づけへ、大
きくシフトしている。1960 年代、2003 年、2007 年あたりに、組織 変容の節目が見て取れる。

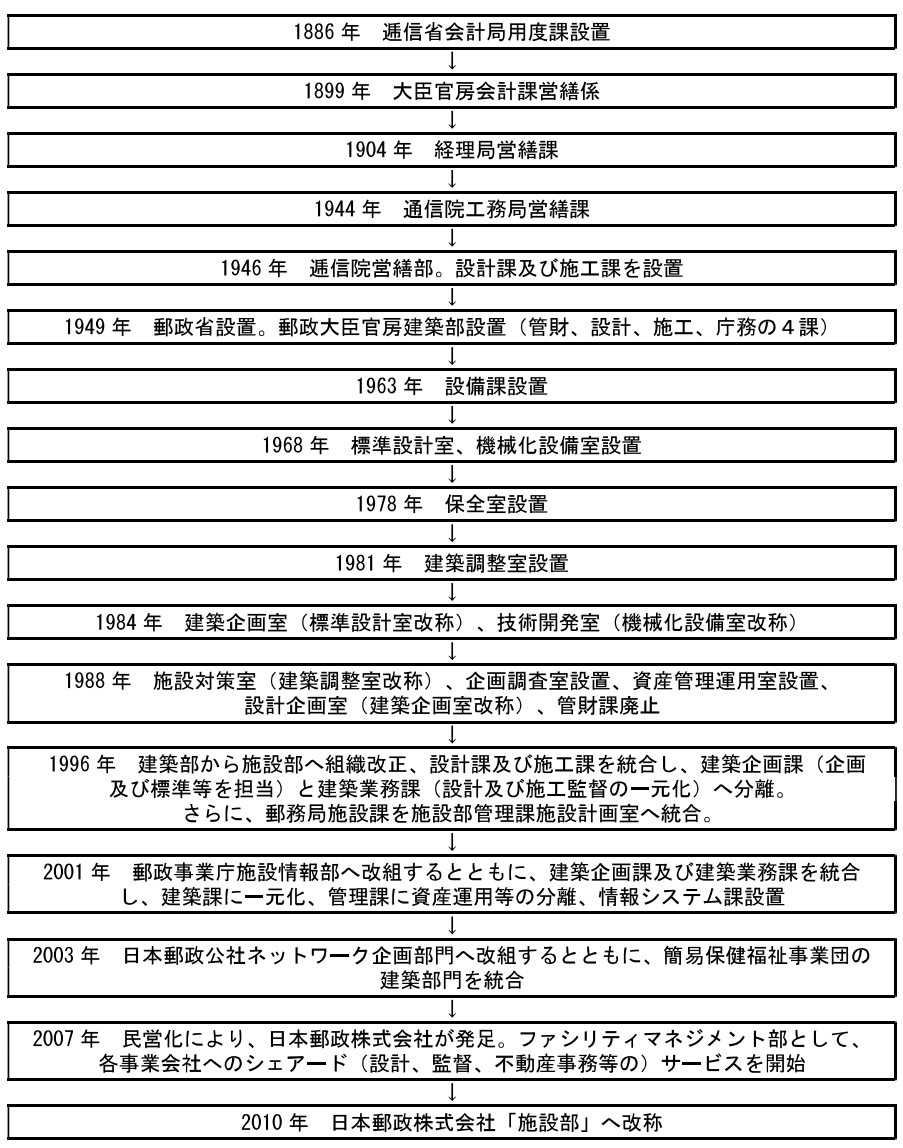

図 3 郵政建築の組織体制の変遷

\section{4-2 発注者機能における変容過程}

発注者の一員として、郵便局を所管する郵務局等があったものの、 個別予算の執行にあたっては、全体予算の範囲内で設計者が属する

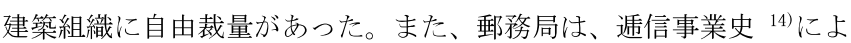
れば、主に、改善局の選定、場所、必要な面積規模等の最低限の発 注者要求を提供する一方、デザインや配置計画等については、基本 設計及び実施設計において郵務局や現地局との協議やすり合わせが 必要であったものの、基本的に建築組織の設計者が自由に決められ る余地が大きかった。特に、工事発注については、郵政省設置法 （1948）において、建築部の業務として「(1)各部局の要求する不動 産工事の設計及び施工をすること、(2)不動産に関する工事の契約を すること」とされており、建築組織に一任されていたことなどもあ り、比較的、発注者として、建築組織に決定できる大きな権限があ ったと推定できる。立花 $\left.{ }^{10}\right)$ は、莪信省時代の設計の考え方を続・逓 信事業史の中で、「設計者の業務を設計図書の作成までに終わらせ ないで、工事現場の現寸図見本品の検討にまで拡げ、設計の意志を 建物細部にまで浸透させ、あわせて組織の拡大、分業化による弊害 に対処した。」と指摘しており、設計者が主導していた組織である ことがわかる。この体制は 1960 年代まで、形を変えながらも、発注 者として、または発注者の代理人として、自らの設計に基づき、そ の設計を実現するため、発注者としての権限を背景に、設計者が監 督員となって指導的に監督を実施してきた。逓信省の設立当初から、 
発注者要求と設計品質の確定が、設計者に大きく委ねられていたこ とから、「要求品質」注 3) と「設計品質」注 ${ }^{3)}$ の両方を確保するため の、設計者の役割は大きかった。聥信省設立からここまでの設計者 は、発注者としての役割を担う発注者機能と設計者としての役割を 担う設計者機能を合わせ持っていたことに特徴があると言えよう。

1970 年代になると、工事量が増加する一方、施工者側の品質管理 についても TQC、IS09000 の導入、WTO 政府調達協定の発効等を契機 として契約関係の明確化等、施工者の技術力の向上もあり、発注者 としての建設工事プロセスへの関与も、発注者自ら「施工品質」注 33 を確保する要素が減少し、検查を充実させる体制へと変化している。 1980 年代になると、ほとんどのプロジェクトで実施設計の外注化 が一般化したり、一部プロジェクトで、基本設計からの外注化が実 施されたりもした。発注者としての建築プロジェクトへの関与の重 心がプロジェクトの川上段階ヘシフトした。

公社化以降は、建築工事と設備工事を分離することなく、建築一 式工事として発注することが一般化した。更に発注者機能へ特化し、 建築を基本設計から実施設計、工事に至るまで自ら「作り込む」体 制から、要求性能を明らかにしたうえで、工事も含め外注先に作っ てもらったものを「買う」体制へと、大きく変化している。

2007 年の民営化により、発注者機能が郵便会社等の子会社へ分離 されたため、建築組織は受託者へと位置づけが変化している。

発注者機能の変容は、聥信省時代から 1970 年代まで続いた発注者 として必要な建物を確保するため「要求品質」と「設計品質」を確 定し、その担保のために「施工品質」を作り込む段階から、1970 年 代、施工者の自主管理へと「施工品質」を委祇「要求品質」と「設 計品質」を重視した時代へと変容している。1996 年に設計者機能と 監督員機能が組織統合された結果、発注者機能が川上段階における 「要求品質」の確定へと特化する形で、プロジェクト全体に対する 発注者としての関与を減らすような形へとシフトしている。さらに 2007 年の民営化以降は、発注者機能が分離している。このあたりに、 発注者機能の変容の過程が見て取れる。

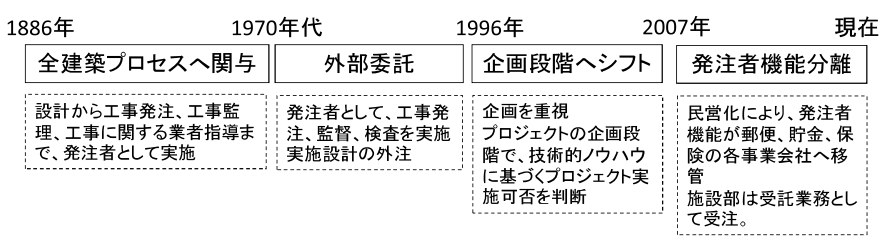

図 4 発注者の関与

\section{4-3 設計者機能における変容過程}

莪信省における設計者は、当時の民間に比して優れた技術力を背 景に、設計者を中心とする建築プロジェクトを推進する体制が構築

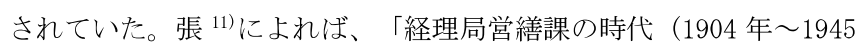
年）において、設計部に所属する設計技師がプロジェクト毎にチー ムを編成し、設計技師がプロジェクト全体を統括し、設計を進める。 設計会議を経て $1 / 100$ 図面を莪信局に照会し、使用者側の視点で若 干の見直しが行われながら、設計が進められた。工事発注後の工事 監督についても、設計者がそのまま莪信省の監督員として、主任や 技師の上に位置し、自ら実施する。」、「設計班は技師に 1 班 8 9 名ずつの人員を属せしめて、一つの局舎の設計は各々その班で䋔め
ることになっている。」と指摘している。技師は今で言うアトリエ 事務所の建築家としてプロジェクトチームの中心として位置し、構 造や設備等の専門技術者は技師の意匠実現をサポートする形で進め られた。この時点において、設計者自らが、設計者機能に加え、設 計変更等の決定など発注者機能も有する形で展開される基䃈ができ ており、規模や各室面積調書以外の「要求品質」を、設計者自ら設 定し、解を導くことができる環境が、設計者により構築されていた。 結果として、「要求品質」を確定するプロセスにおいて、発注者 要求を踏まえて確定された設計情報は、発注者満足度の高い「設計 品質」が設計者によって確保されていたと言える。「施工品質」に ついても、設計者が監督員となることで、設計情報の転写ミスを少 なくすることで、品質確保が担保されていたことがわかる。この時 代、郵政建築においては、設計者を中心に、一貫して「要求品質」、 「設計品質」、「施工品質」を確保する体制が構築されていたのが、 ひとつの特徵である。

1974 年以降、大きく変容したのが、「施工品質」の確保方法であ る。常駐監督から 1974 年に非常駐（臨機(月数回出張することで監 督行為を実施すること））監督となると、監督員の役割も施工者に委 ねる部分が大きくなり、抽出検查を主体とする監督方法に切り替わ った。また、これを契機に設計者と監督員の役割が明確化され、施 工者への指示等は監督員が実施することとなったため、設計者の直 接的関与は材料や色の決定に限定された。更に、業務量の増大に伴 い、標準化、郵政建築に精通した設計事務所の設立等もあり、郵政 において実施設計の外注化が一般化したのも 1980 年代である。

1996 年には、設計課と施工課を統合再編し、主に環境や企画等を 担う建築企画課、従来の設計や監督といった実務機能を統合した建 築業務課へと組織再編した。その背景には、企画段階における基本 設計及び予算策定、地球環境配慮、資産活用、ニニバーサルデザイ ン、ファシリティマネジメントなど、川上段階における計画や企画 が重視されるようになったこと、設計者と監督員に専門分化した組 織の意思疎通の円滑化する必要があったこと等、がある。またこの 時代、先に述べたように実施設計の外注化も進んだため、企画段階 における発注者機能を強化し、性能発注等も含めて発注者要求を明 確化することが求められた。従来の設計者においても「要求品質」 の確保が「設計品質」以上に優先された。さらに、大規模な郵便局 や大型の宿泊施設等の整備において、搬送技術や舞台装置など主要 な技術を外部依存する形となったため、設計者の役割が専門家全体 を束㸚てプロジェクトを管理するような形の「プロジェクトマネジ メント機能」へと、大きく変わる契機となった時代である。

2003 年の公社化以降は、業務の中心が修繥や維持管理を中心とし た全国一斉改修等の大量発注への対応、そのための建設予算の策定 など、企画的な業務が増加し、設計者の役割が設計業務から、さら に「プロジェクトマネジメント機能」へと大きくシフトしている。

2007 年の民営化以降、これまで保有していた発注者機能が事業子 会社に明確に分離されたため、プロジェクトマネジメントが強化さ れている。また、民営化に伴い不動産事業を実施することが可能と なったため、不動産事業対象敷地における都市計画手法を使った開 発想定プランの作成や予算等の策定、都市計画協議、賃貸オフィス ビルの基本計画など、不動産事業における企画段階の業務が、新た に設計者の業務として加わることとなった。 
設計者機能について、1974 年以前は、設計者が工事段階において も、細部に至るまで設計意図を実現していたのに比べ、1974 年以降 は、設計者と監督員の機能分化へと変容している。1990 年代になる と、実施設計の外注化や組織改正に伴う設計者と監督員の融合と設 計者とは別組織としての企画段階の強化、2003 年の公社化に伴い設 計者機能が主にプロジェクトマネジメント機能へ大きくシフトして いることがわかる。図 5 は、主に設計者が主体となって実施する業 務の推移を示したものである。なお、図中のPMr はプロジェクトマ ネジャーを示すが、実態として設計者が関与する場合が多い。

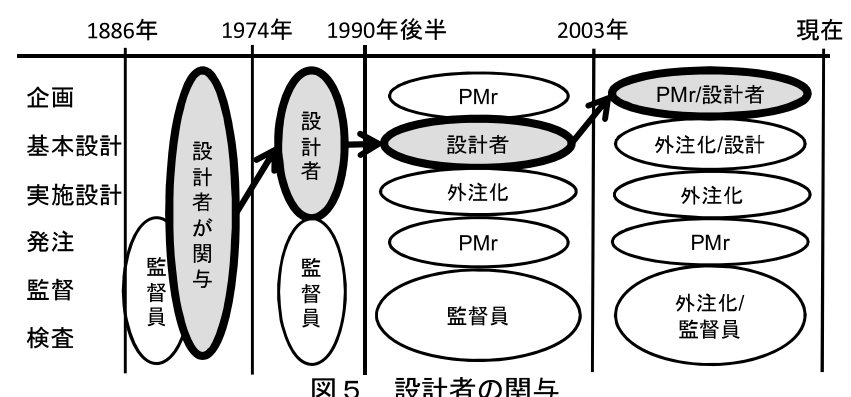

\section{4-4 監督員機能における変容過程}

郵政建築は、設立当初から新しい技術を導入することに積極的な 組織であった。たとえば、当時、建築技術において日本国内に導入 が始まったばかりの鉄筋コンクリート造を 1918 年から積極的に局舎 建設に導入している。インタビューによれば、1970 年代まで、コン クリート打設時は郵政の監督が総責任者として現場を指導監督して いたとのこと。監督員である逓信省の技術者が、比較的高い技術力 を背景に、直接作業細部の工事指導まで行っていた実態が伺える。 施工図についても、郵政の監督員が建具図・躯体図を除く主要な施 工図作成なども実施しており、直接、施工者を工事指導する監督体 制が 1970 年代まで続いている。1971 年に「建築施工監督要領」16) を策定しているが、同要領の「施工図」は、「特に重要な箇所およ び基本になる図面は努めて監督員自ら製図する。」こととしていた。 ところが、1972 年の公共工事契約約款の改正、工事量の増加等を 契機に、1974 年から、監督体制が現場常駐から非常駐(臨機)へと監 督体制が変更になった。当時、建築プロジェクトの監督員は施工課 に属する職員により、主任者（=主任監督員）の下数名の監督員で 構成され、グループ監督制 ${ }^{18)}$ を採用していた。また、設計出身の若 手教育を除いて、あくまで現場の監督員業務は郵政の施工課の監督 員で完結する体制を構築していた。

これまで伝統的に郵政の監督員自ら工事指導を行うような体制を 構築してきたが、この体制を維持することも当然できなくなった。 郵政における監督の方法も、抽出検査や施工者の自主検査の確認へ と変更するなど、工事指導の監督から検査主体へと大きく変わるこ ととなった。1981 年の「建設工事 監理方針」17)では、監督自らが 施工図を作成する、との項目はなくなっている。

工事監理についても、施工者の品質管理能力の向上、双務契約の 実施もあり、「指導監督型監理」から「自主管理確認型監理」へと 変化している。

1985 年には、施工品質を管理するため、現場での寸法等の押えや
チェックすべき品質管理項目を定めた実務ガイドラインとしての 「工事管理チェックシート」 ${ }^{19)}$ を作成している。同じ年に、「建設 工事検查要領」20)を制定し、会計法に基づく検査職員の視点を統一 するなど、品質確認の方法を定義している。1988 年には、「公共建 築工事施工計画書の作り方と実例 ${ }^{22)}$ (郵政大臣官房建築部施工研究 会編）」、「品質管理ガイドライン ${ }^{23)}$ （郵政大臣官房建築部施工 課）」を制定するなど、監督業務を支援するツールとともに、共通 に施工者の目指す心゙き品質管理目標を規定することで、監督業務の 簡素化・標準化を図っている。

また、1988 年に新東京郵便局（延床面積約 10 万 7 千 $\mathrm{m}^{2}$ ）をはじ め、大規模郵便局の建設がはじまると、同時期の大量発注もあり、 監督員業務が急増することとなった。増加するプロジェクトに対処 するため、監督業務の効率化、発注者体制としてのあり方を見直す 「工事監理業務の効率化の研究報告書 (1994 年)」 ${ }^{21)}$ がまとめられて いる。この報告書では、単に工事監理の合理化、効率化にとどまら ず、発注組織としてのあり方についての提言もあり、その後のプロ ジェクトマネジメント組織の構築に向かう契機となっている。

1995 年からは WTO 政府調達協定が締結及び公布され、一定額以上 の工事が国際入札となり、「国際化」への対応 ${ }^{25)}$ が必要となった。 そのため、発注後に決定するような事項を削減するなど、設計の確 定度合いを高めたり、仕様書の詳細化等が進んだりした。

一方で、1990 年代後半から、監督が実施してきた施工計画の策定 においても、建設費の削減を求めるため、駐車場を地下から地上へ 変更するなど、建設コス卜縮減の要請や事業環境の変化に伴い、地 下工事、地下仮設工事が減少したため、複雑な仮設計画を検討する 必要性が薄れた。その結果、単純な仮設計画が増加し、自ら仮設計 画を作成する機会が減少するなど、監督員の技術力を維持しつづけ るための建築プロジェクト環境が大きく変化した時代でもある。

また、郵便局という特殊な建物を建設していたこともあり、設立 当初から郵政独自の仕様書をベースに独自に設計、積算、施工を実 施していた。施工者も郵政の施工品質を確保するために、インタビ ューによれば、郵政の現場を経験した工事現場所長が地域を超えて、 次の郵政の現場へと異動したり、施工会社としても積極的に郵政の 現場を経験することで技術を学ぶ経験を社員にさせたりするなど、 独自の仕様と高い技術力を背景に、官庁営繥組織の中でも高い評価 を得ていた。しかし、2003 年に、官庁営繕関係基準類の統一化によ り「公共建築工事標準仕様書」が統一基準として決定した結果、郵 便局庁舎に関寸る標準詳細図は残ったものの、急速に、郵政建築の 独自性が失われた。監督員も独自仕様に基づく施工者への指導機会 が失われる結果となっている。

さらに、2003 年以降の公社化により郵便局を含めた建物の新築が 抑制されるとともに、民営化以降の郵便局プロジェクトではコスト 削減が強く求められたこともあり、仕上げグレードの簡素化や単純 化、更には標準化が進んだ。その結果、施工技術も単純化されたた め、より施工者任せとなる部分が大きくなった。更には、2007 年の 民営化以降、職員の増強が難しかったことから、監督員業務の一部 （日常検查業務等）についても、監督補助業務として外部委託が始 まっている。

郵政の監督員業務は、現場に常駐して工事指導を直接実施するこ とで、「施工品質」を確保する方法から、1974 年の監督体制の変更 
により非常駐（臨機）となり、施工者の技術力へ依存する形で出来 形確認・検查を主体とする監督方法へと大きく変化している。2007 年以降は、工事監理補助業務などの外部依存が進み、監督業務の軽 減が図られるなど、監督員機能の変容が見られる。

郵政と同様の営繕組織として建設省官庁営繕部があるが、羽田野 5)らの研究にもあるように、郵政同様、社会環境の変化に応じて外 部化が進んだ。しかし、郵政と比較すると、営縜では筑波学園都市 開発にあわせ、早い段階で設計外注化や第三者監理を導入するなど、 外注化のスピードに違いが見られる。

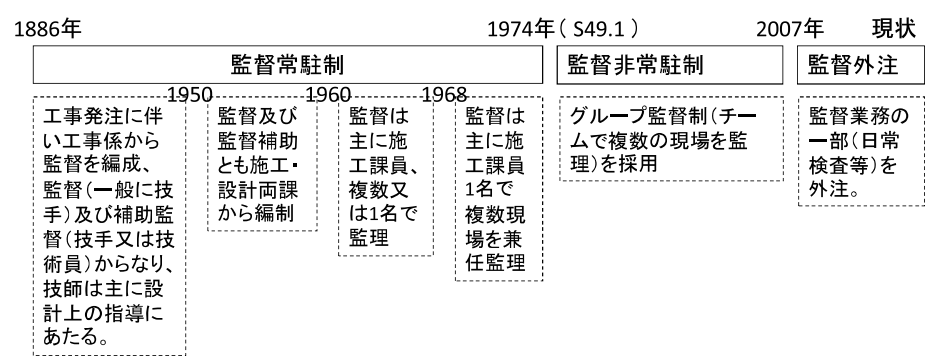

図 6 監督員体制の推移

\section{5 考察}

以上の分析を踏まえ、郵政建築における建築生産システムの変容 過程において、次のようなことが明らかになった。

（1）明治期においては「発注者」の意図をすべてに獄底させるた め、「設計者主導」を組織的に確立し、逓信建築、郵政建築の 伝統を創造する時代が昭和中期、1960 年代まで長く続いた。

「設計への拘り」は、むしろ発注者としてきちんとした品質を 確保した質の高い建築を生み出すために、当時の相対的に低い 施工者の技術力や設計者が十分育っていない環境を踏まえた選 択肢であったと言える。

（2） 1970 年代の高度成長と共に、郵便局の建設投資額が増加し、 プロジェクト数が増えるにつれ、設計者が監督員を兼務するよ うな形での作り込みが難しくなった。1974 年に監督員が非常駐 (臨機) となるに伴い、職能分化が進み、設計者、監督員の役 割機能を分離し、専門分化が進んだ。設計者も意匠設計、構造 設計、設備設計へと専門分化し、監督員も、建築監督、設備監 督と専門分化している。発注者機能もそれぞれが分担して担当 している。

（3） 1990 年代になり、設計と監督の組織に分かれ専門分化が進み すぎたため、工事現場における設計意図の一貫した実現が阻害 されるなど、部門間の連携に課題が生じることとなった。そこ で、設計組織と監督組織を統合寸る形での設計から積算、工事 監理まで含む一貫したプロジェクト管理を実現するために、 1996 年に組織の集約化を図った。

（4） 1996 年以降は、郵政の組織自体、郵政省から郵政事業庁、日 本郵政公社へと変わる中で、新築工事が激減し、相対的に維 持・修繕工事が増加することとなった。この時代、設計よりも 全国一斉に発生する大量発注、改修工事のためのマネジメント 機能が重視されるようになった。

（5） 2003 年に公社化すると、新築工事から維持管理へのシフトが
更に進み、一方で、公共工事のコスト縮減 (2003 年)や公共工事 の品質確保 (2005 年)等の施策もあり、民間にできることは民間 に任せるべしと言った形で、基本設計の外部委託や工事監理業 務の一部外部委託など、外部依存、外部化が進んだ。より川上 指向が強くなり要求品質を確定させるための発注者機能一の特 化も進んだ。2007 年の「民営化」で、日本郵政株式会社へと移 行するに従い、発注者機能と設計者機能が分離し、郵政グルー プ内へ設計や監督といった設計事務所業務をシェアードサービ スとして提供するグループ内設計事務所としての機能を強めて いるのが、現在の郵政建築である。

以上を整理すると、郵政建築における建築生産システムの変容過 程において、次のようなことが見て取れる。

(1) 1886 年〜 1970 年代の「設計に拘る」設計主導の時代

(2) 1970 年代 1990 年代の「監理に拘る」専門分化の時代

(3) 1990 年代〜2003 年までの「マネジメントに拘る」マネジ メント化の時代

(4) 2003 年〜現在までの「外部化・民営化」の時代

ここまでの変容過程の分析を踏まえて、郵政建築における建築生 産システムの変容を把握するうえで重要な意味を持つ、次のような 「変換点」を暫定的に見出すことができた。

（1) 公共建設工事請負契約約款の双務契約への改正、それを踏 まえた設計者と監督員業務の体制を大きく改訂（非常駐（臨 機）化）した時期

(2) WTO 協定の発効、ISO 導入の動き等により、外部技術力の 導入を促進し、企画段階へ組織改正した時期

(3) 国から独立し、公社化によりプロジェクトマネジメント機 能へ大きくシフトした時期

これらの変換点と目される間を、郵政建築は「設計に拘る」 $\rightarrow$ 「監理に拘る」 $\rightarrow$ 「マネジメントに拘る」という形で建築生産シス テムを変えていったと推察できる。

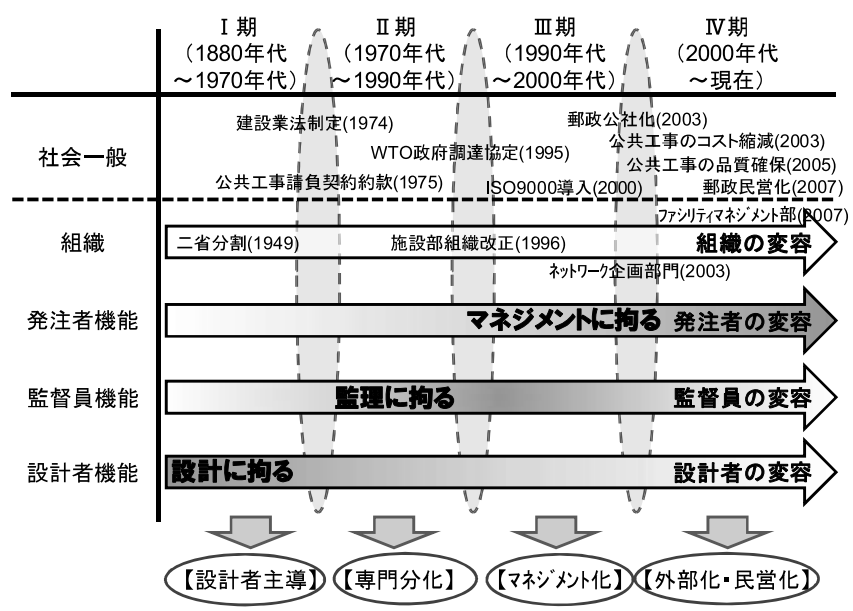

図 7 郵政建築における建築生産システムの変容

今後は、本研究における変容過程を踏まえ、それぞれの時代区分 におけるより詳細な分析を行うことで、郵政建築における建築生産 システムの変容に至った要因を明らかにする。さらには、発注者の 役割、責任のありようについても、今後、明らかにしていきたい。 


\section{参考文献}

1）神代雄一郎、阿部公正：建築学体系第 6 巻、日本近代建築史、1958

2) 丹羽 和彦、小原 誠：山田 守と「ある電話局の草案」大正後期の逓信省 建築に関する研究 その 1、日本建築学会計画系論文集 No. 513、pp285-292、 1998. 11

3）李 明、石丸 紀興 : 広島莪信診療所の建築について日本建築学会計画系論 文集 No. 540、pp307-314、2001.2

4）西野 佐弥香、高松 伸、古阪 秀三、平野 吉信 : 東京都美術館の建築プ ロセスにおける設計内容の確定過程、日本建築学会計画系論文集 No. 654 、 pp149-187、2010.8

5) 羽田野将生 : 戦後の官庁営繥組織における業務機能の外部化に関する研究、 京都大学大学院修士論文、京都大学、2012

6）水川尚彦、古阪秀三、金多隆、藤本真一 : 建築プロジェクトの発注者支援 業務に関する研究、日本建築学会計画系論文集 No. 598、pp165-170、 2005. 12

7）李 垠錫、嘉納成男：日本と韓国における発注者の意識に関する研究、日 本建築学会大会学術講演梗概集. F-1、pp1355-1356、2005

8）齋藤隆司、古阪秀三、峰政克義：公共工事における「工事監理」に関する 研究、日本建築学会計画系論文集 No. 574、pp145-152、2003. 12

9）齋藤隆司、古阪秀三、金多隆、李ヨウ：工事監理に関する国際比較研究、 日本建築学会計画系論文集 No. 594、pp109-115、2005.8

10）立花量吉：郵政建築第 23 号、続我信事業史建築編序説、1960.3

11）張菅雄 : 高等建築学 第 19 巻、逓信省の建築、常盤書房、1933

12）郵政大臣官房建築部・郵政省施設部：郵政建築、1958-1997、郵政建築協 会

13）郵政・施設総合情報センター：ゆうせい・しせつ、郵政事業庁施設情報 部監修、1997-2001

14）前島会 : 逓信事業史、続第 9 巻、（執筆者：青木秀男、高松竜、末田計 雄、小沢式行、安藤司郎、柴喜久雄、檜山奥、安藤政義、木村光人、吉田 秀行、菅原正夫、小川茂、立川玄一郎、川崎鋼次郎、玉野義徳）、1962

15）国土交通省総合政策局：9-21 建設デフレーター、総務省統計局ホーム ページ (http://www. stat.go.jp/data/chouki/09.htm) (参照 2014.11.30)

16）郵政大臣官房建築部：建築施工監督要領、1971.3

17）郵政大臣官房建築部：建設工事監理指針、1981

18）郵政大臣官房建築部：郵政建築 100 年、郵政建築協会、1991

19）郵政大臣官房建築部：工事管理チェックシート、1985

20）郵政大臣官房建築部：建設工事検査要領、1985. 12

21）郵政大臣官房建築部施工研究会編：公共建築工事施工計画書の作り方と 実例、1988. 1

22）郵政大臣官房建築部施工課：品質管理ガイドライン、1988.2

23）（社）日本建築学会：工事監理業務の効率化の研究報告書、1994

24）(財) 建築コスト管理システム研究所：郵政省施設建設における国際規格 に対応した品質管理システムの構築に関する研究報告書、1999

25）石井昭：工部省の営繥事務について、日本建築学会論文報告集第 60 号、 pp669-672、1958.10

26）稲垣栄三：日本の近代建築、鹿島出版会（SD）、1979.6

27) 関口宏之、近江栄 : 大蔵省営繥管財局の設計体制について：官庁営繕機構 とその意匠の近代化、日本建築学会大会学術講演梗概集. F、pp779-780、 1988. 10

28）郵政省：郵政百年史第 27 巻、吉川弘文館、1971

29）郵政建築研究センター：郵政省の建築（戦後の木造庁舎）、1985

30）郵政・施設総合情報センター：郵政施設研究、郵政事業庁施設情報部監 修、1997-2001

31）郵政大臣官房建築部施工課「建築工事管理資料 工事管理のす寸女方」 1987

32）（社）日本建築学会 : 郵政型 VE/VM のあり方に関する研究報告書、1999

33）南一誠 : 悉皆調査と追跡調査による郵便局庁舎の修繕・改修工事に関す る研究、日本建築学会計画系論文集 No. 565、pp269-275、2003.3

34）峰政克義、古阪秀三、齋藤隆司：「工事監理」業務の再構築、日本建築 学会建築計画系論文集 No. 565、pp301-307、2003.3

35）日本郵政：郵政建築 逓信からの軌跡、建築画報社、2008

\section{注}

注 1） 2014 年に、国土交通省において、社会資本の整備・管理を適切に実施 し、将来にわたって安全なインフラサービスを継続的に提供するシステム を構築することを目的に設置された。
注 2) 本論における郵政建築における「発注者」とは、郵政の建築プロジェク 卜において発注者機能を有する者という意味で用いている。郵政省であれ ば、当時の郵務局施設課、大臣官房建築部の管理課、設計課、設備課、施 工課など建築プロジェクトにかかわる職員がそれぞれ発注者としての機能 を有していたことになる。

注 3）日本建築士会連合会の「建築と工事監理（1994 年）」における、「要 求品質」、「設計品質」及び「施工品質」を参考に、本報告では、以下の ように定義している。

「要求品質」: 発注者の顕在的、潜在的要求に関する発注者要求の確定度合い 「設計品質」：基本設計情報及び詳細設計情報と要求品質（発注者要求）にギ ヤップが少なく確定しているかの度合い

「施工品質」：中間生産物及び最終生産物が設計品質（設計情報）との適合性 を確保しているかどうかの度合い 


\title{
HISTORICAL STUDY OF POSTAL ARCHITECTURE SYSTEM AND MANAGEMENT
}

\author{
Takashi SAITO*, Shuzo FURUSAKA** and Yoshinobu HIRANO*** \\ * Deputy Senior General Manager, Japan Post Co., Ltd., M. Eng., M. Sci. \\ ** Assoc. Prof., Dept. of Architecture and Architectural Eng., Kyoto University, Dr. Eng. \\ *** Prof., Dept. of Architecture and Architectural Eng., Hiroshima University, Dr. Eng.
}

The Japanese construction industry has faced on the problems, such as increasing construction cost which brings by Abe-nomics, booming economy, and quality assurance in architectural projects occurring variety of quality errors. The Japanese construction client lives in the risk free side, so that they simply order their requirements to contractors, and the contractor itself make progress in projects automatically. This relationship was based on long term contract between a client and a contractor. Contractor expect to receive next contract from the client, therefore the contractor automatically receive client's requests to project. But, it has a lot of difficulties to keep this relationship at present because of lack of long term relationship. It is easily imagined that client's involvement to construction projects has become much more important to keep construction quality.

The postal architecture was born in 1885, with over 130 years' historical accomplishment. The postal architecture has been producing variety of buildings into the Japanese society such as post offices, postal workers' hospitals, employees' apartments, etc. It has the feature which has secured the quality of postal administration construction, and the appropriateness of manufacturing system as a designer or a supervisor, being based on change of social environment, continuing holding client function, in order to fix the specific building centering on post offices since the early of 1880s.

The postal client secured construction quality by participating in construction process by itself, when the general contractor's technical capabilities are relatively low than technology of postal architecture.

This system has secured the quality of post office's buildings required, and the appropriateness of manufacturing system.

This paper analyses the influence of postal architecture's quality assurance from the view point of client side. The postal architecture is very unique tradition that it has the strength of having both clients function and architects function.

As it became clear in analysis, it was able to be shown clearly that the era of postal architecture has been divided into 4 phases from the viewpoint of quality assurance; 1) the era of in-house designers who lead building projects, 2) era of specialists, 3) era of project management, 4) era of externalities and privatization.

I make conclusion why these changes occurred in the times of the postal administration architecture, based on era of the postal architecture developing process.

The role of the client in the postal architecture greatly changes in the change of the times. A client in postal architecture carried it out all construction process such as design, supervision, and construction management by himself. The dependence of design firms and contractors in postal architecture progressed because of the improvement of quality assurance by these firms. As the result of it, the degree of participant as the client in postal architecture decreased, and it became to face on difficulties to maintain quality assurance by the client. The role of client also declined.

It will become big issue in future about the secure of the project quality assurance in the process of outside technology greatly changes, and the future clients should decide how they involve to their construction projects by themselves.

This paper analyses the changing role of clients and how the environment society has been influenced these changes. This paper also shows some possibilities to adopt postal architecture's strength to the project management of construction projects. 